\title{
Penggunaan Perangkat Lunak ATP untuk Mahasiswa Calon Guru SD Memahami Profil Perkembangan Siswa
}

\author{
Arie Rakhmat Riyadi, Tatang Syaripudin, Kurniasih, N. D. Shiera, Ari A. Magistra \\ Universitas Pendidikan Indonesia \\ arie.riyadi@upi.edu
}

\section{Sejarah Artikel}

diterima 28 Oktober 2020 disetujui 20 November 2020 diterbitkan 1 Desember 2020

\begin{abstract}
Understanding child development is essential for a prospective teacher. The purpose of this study is to determine the impact of the use of the ATP software (Developmental Task Analysis) on the understanding and the skills of the prospective elementary school teacher in describing the profile of student development tasks. The method of the research is ex post facto with a quantitative approach. The research subjects are 288 primary school teacher candidates at one of the leading state education universities in Indonesia. The data collected uses a questionnaire. Data analysis performed assisted by SPSS. The results showed ATP improved students' understanding and skill in describing the levels and aspects of the student's development task profile. The study's conclusions emphasize that ATP facilitates the achievement of the objectives of the subject of Student Development in Elementary Schools; that's why involving ATP recommended continuing in similar topics.

Keywords: ATP, development task, profile, prospective teacher, software
\end{abstract}

\begin{abstract}
Abstrak
Memahami perkembangan anak merupakan hal penting bagi seorang calon guru. Tujuan penelitian ini mengetahui dampak penggunaan perangkat lunak ATP (Analisis Tugas Perkembangan) terhadap pemahaman dan keterampilan mahasiswa calon guru SD dalam mendeskripsikan profil capaian tugas perkembangan siswa. Metode penelitian ini ex post facto dengan pendekatan kuantitatif. Subjek penelitian adalah mahasiswa calon guru SD berjumlah 288 orang di sebuah universitas negeri pendidikan terkemuka di Indonesia. Alat pengumpul data menggunakan kuisioner memanfaatkan google form. Analisis data berbantuan SPSS. Hasil penelitian menunjukkan penggunaan ATP meningkatkan pemahaman dan keterampilan mahasiswa mendeskripsikan profil capaian tingkatan dan aspek perkembangan siswa. Simpulan penelitian menegaskan bahwa ATP memfasilitasi pencapaian tujuan perkuliahan Perkembangan Peserta Didik di SD, sehingga melibatkan ATP direkomendasikan pada mata kuliah sejenis.

Kata kunci: ATP, tugas perkembangan, profil, calon guru, perangkat lunak
\end{abstract}




\section{PENDAHULUAN}

Akhir-akhir ini pelibatan teknologi menjadi bagian dari penilaian kualitas proses belajar mengajar di sekolah (Uerz et al., 2018). Sebagaimana diringkas dari Uerz et al. (2018) bahwa perkembangan mempengaruhi profil guru yang diinginkan.

Harapan terhadap kinerja guru lebih meningkat karena diasumsikan bila teknologi dilibatkan maka kualitas proses belajar mengajar menjadi lebih berkualitas. Pada bagian lain, guru yang melibatkan teknologi dalam pembelajaran meningkatkan literasi teknologi siswa di abad 21. Secara komprehensif diungkap Agyei \& Voogt (2011); Drent \& Meelissen (2008); Sang, et. al. (2010); Tondeur et al. (2012) dalam Uerz et al. (2018) bahwa calon guru harus dibekali keterampilan pemanfaatan teknologi untuk mendukung litarasi teknologi siswa.

Selain untuk proses pembelajaran, kemajuan teknologi dapat dimanfaatkan untuk memahami karakteristik perkembangan siswa (Dina, 2020). Gibson \& Mitchell (Dina, 2020) mengatakan bahwa need assessment (analisis kebutuhan) adalah kunci bagi perencanaan. Dalam konteks pembelajaran di SD, guru perlu melakukan analisis profil capaian tugas perkembangan siswa agar memudahkan perencanaan tindakan perlakuan termasuk pembelajaran yang tepat. Latifa (Dina, 2020) mengemukakan bahwa perkembangan siswa berpengaruh terhadap proses belajar di kelas.

Pemahaman tentang karakteristik umum siswa, juga karakteristik keluarganya termasuk kompetensi esensial bagi seorang guru. Menjalin hubungan dengan siswa tanpa dasar pengetahuan yang lengkap tentang profil siswa dapat berdampak buruk. Kedekatan guru dengan siswa dapat dicapai bila perlakuan yang diberikan guru didasari pemahaman yang benar tentang anak. Apabila hubungan positif terjalin dengan baik, dipastikan terdapat kedekatan yang membangun perilaku prososial anak (Coulombe \& Yates, 2018). Hubungan yang dibangun oleh guru dengan siswa, terutama pada masa transisi sekolah, dapat berpengaruh terhadap pembentukan perilaku (Silver et al., 2005).

Penelitian ini fokus pada pemanfaatan teknologi dalam memahami perilaku siswa. Keterampilan dalam memanfaatkan teknologi terutama perangkat lunak selain untuk proses pembelajaran lebih jauh penting juga digunakan untuk mendalami karakteristik perkembangan siswa.

Berdasarkan dokumen Pedoman Pelaksanaan Penilaian Kinerja Guru (2010) disebutkan bahwa salah satu aspek dari kompetensi pedagogik adalah kewajiban guru menguasai karakteristik peserta didik. Hal ini juga sejalan dengan kewajibannya yang lain pada kompetensi pedagogik tersebut adalah mengupayakan pengembangan potensi peserta didik.

Selain itu, penguasaan tentang karakteristik peserta didik secara personal menuntut guru memiliki kemampuan berkomunikasi secara tepat dengan siswa. Tersirat amanat Undang-Undang tentang Sisdiknas No. 20 Tahun 2003 pasal 1 ayat 1 pada definisi pendidikan di dalamnya menegaskan bahwa tugas guru menyelenggarakan pembelajaran dan membangun suasana belajar yang dapat 
memfasilitasi perkembangan potensi siswa secara optimal.

Untuk mendalami profil capaian tugas perkembangan siswa, Prof. Dr. Sunaryo Kartadinata et. al. (Aulia \& Djunaidi, 2017) tahun 2003 mengembangkan ITP (Inventori Tugas Perkembangan). ITP merupakan alat ungkap khusus berbentuk angket jenis paired comparison untuk mengungkap tingkatan (level) dan profil capaian tugas perkembangan siswa mulai dari tingkat SD hingga perguruan tinggi.

Secara lengkap ITP terdiri dari dua bagian, yaitu bagian angket (buku) dan bagian lembar jawab. Guru secara manual membagikan kedua perangkat ITP tersebut ke siswa agar mereka mengisi lembar jawab sesuai dengan respon apa adanya terhadap pernyataan-pernyataan yang ada di buku soal. Lembar jawab siswa dikumpulkan guru dan direkap. Untuk memudahkan pengolahan dan interpretasi data, ITP didampingi oleh ATP (Analisis Tugas Perkembangan), yaitu sebuah perangkat lunak yang ditujukan untuk membantu hasil rekapitulasi data yang diperoleh dari ITP. Saat ini ITP dan ATP telah memperoleh sertifikat HKI (Hak Kekayaan Intelektual) tahun 2014.

Perangkat lunak ATP pada semester genap tahun akademik 2019/2020 dilibatkan dalam proses perkuliahan mata kuliah Perkembangan Peserta Didik di SD di prodi PGSD sebuah kampus kependidikan di Kota Bandung. Tujuan utama mata kuliah tersebut adalah untuk memberikan pemahaman dasar dan keterampilan memahami dan mendeskripsikan profil karakteristik capaian tugas aspek-aspek perkembangan siswa usia SD. Walaupun sudah berjalan dua semester, efektivitas pelibatan perangkat lunak ATP belum diteliti efektivitasnya.

Terdapat asumsi utama bahwa memahami perkembangan siswa berkontribusi terhadap kualitas proses dan hasil belajar. Banyak negara yang memberikan penekanan bahkan sertifikasi khusus bagi penguasaan perkembangan anak pada persiapan calon guru (Daniels \& Shumow, 2003). Bagaimanapun, secara tegas mengapa pengetahuan dan pemahaman mendalam tentang perkembangan anak penting bagi guru terutama dalam pengambilan keputusan pendidikan merupakan tanggung jawab berat pada proses pendidikan guru (Daniels \& Shumow, 2003). Penyiapan calon guru dalam hal penguasaan tentang karakteristik anak didik menjadi esensial bagi pendidikan guru.

Ide yang mendasari istilah childcentered learning adalah pemikiran bahwa yang paling utama dalam proses pembelajaran bukan masalah guru, bukan masalah kurikulum, atau bahan ajar, namun semuanya mengikuti apa yang dibutuhkan oleh siswa. Siswa menjadi pusat konsentrasi perlakuan, mulai dari guru, strategi pembelajaran, bahan ajar, media dan bahkan hingga evaluasi pembelajaran (Pakarinen \& Kikas, 2019).

Salah satu kompetensi pedagogi yang kini menjadi bahasan adalah kemampuannya memahami psikologi, terutama psikologi perkembangan anak (Saeed, 2012). Hasil penelitian Saeed (2012) menunjukkan kelemahan calon guru adalah minimnya pemahaman tentang psikologi anak. Goble et al., (2019) menyatakan awal dari pembentukan kualitas hubungan guru-siswa adalah pemahaman terhadap karakteristik siswa terutama kesiapan mereka 
memasuki lingkungan sekolah. Salah satu yang perlu dipahami oleh calon guru adalah bahwa anak memiliki sejumlah hak untuk dipenuhi. Hak-hak itu dapat dipenuhi oleh guru atas dasar pemahaman yang tepat (Avcl et al., 2014).

Rumusan masalah penelitian ini diarahkan untuk menjawab tiga pertanyaan utama yaitu: (1) bagaimana dampak penggunaan perangkat lunak ATP terhadap peningkatan pemahaman pentingnya memahami perkembangan anak? (2) bagaimana pengaruhnya terhadap pemahaman mahasiswa calon guru tentang aspek dan tugas perkembangan siswa di SD? (3) bagaimana dampaknya terhadap keterampilan mendeskripsikan profil capaian tingkatan aspek-aspek tugas perkembangan siswa di SD?

\section{METODE}

Metode penelitian ini ex post facto. Metode ini dipilih karena penelitian ini termasuk desain noneksperimental. Variabel yang diteliti adalah pendalaman dari sebuah hasil dari perlakuan yang bersifat tidak terkontrol. Penelitian ini tidak mengkhususkan perlakuan yang didisain seperti eksperimen (Akinlua, 2020).

Pendekatan penelitian ini adalah kuantitatif, sehingga data-data yang diungkap hasil penjaringan terhadap subjek penelitian menggunakan kuisioner diolah menggunakan ukuranukuran statistik. Kuisioner dibuat dalam bentuk Google Form dan diberikan kepada subjek penelitian setelah peristiwa perlakuan (perkuliahan mata kuliah Perkembangan Peserta Didik di $\mathrm{SD})$ usai dilaksanakan. $\mathrm{Di}$ dalam kuisioner tersebut terdiri dari dua bagian, yaitu pernyataan yang diinternalisasi sebelum dan sesudah perkuliahan. Subjek penelitian ini sebanyak 301 orang, akan tetapi karena ada 13 data dari subjek yang tidak jelas hasil penjaringannya, maka jumlah subjek yang diolah totalnya 288 mahasiswa.

Secara prosedural, penelitian ini baru dilakukan setelah perkuliahan berlangsung. Mahasiswa diminta untuk mengisi kuisioner pada google form yang dikembangkan peneliti. Kemudian data yang terjaring direkapitulasi, kemudian diolah berbantuan perangkat lunak SPSS. Cara melakukan analisis data berbantuan SPSS diawali dengan melakukan uji normalitas data yang hasilnya ada pada kategori normal. Lalu data secara di analisis secara deskriptif menggunakan teknik statistik sederhana seperti distribusi frekuensi, nilai perolehan presentase (\%) dan komparasi diagram garis untuk melihat kesenjangan data.

\section{PEMBAHASAN}

Pengolahan data secara empiris berbantuan SPSS menunjukkan sejumlah hasil penelitian. Setiap hasil penelitian diungkap, beragam pembahasan disajikan sebagai penguatan perspektif teoretik atau penelitian terdahulu yang relevan.

Pertama.

Perbandingan pemahaman tentang manfaat memahami profil capaian tugas perkembangan siswa SD sebelum dan 
sesudah perkuliahan menunjukkan peningkatan yang cukup drastis. Dalam persen (\%) mahasiswa pada kategori sama sekali tidak memahami sebanyak $35.8 \%$ dan kategori kurang memahami sebanyak $46.5 \%$. Sementara itu, mahasiswa pada kategori cukup memahami sebanyak $14.2 \%$, sedangkan mahasiswa dalam kategori memahami sangat rendah dengan presentase sebanyak $3.1 \%$. Terakhir mahasiswa dalam kategori sangat memahami hanya $0.3 \%$.

Setelah dilaksanakan perkuliahan tidak ada lagi mahasiswa pada kategori sama sekali tidak memahami (0\%). Sementara itu, mahasiwa pada kategori kurang memahami menurun menjadi $1.7 \%$. Mahasiswa di kategori cukup memahami sebanyak $16.3 \%$, dan mahasiswa pada kategori memahami meningkat menjadi 58\%. Kemudian mahasiswa pada kategori sangat memahami meningkat menjadi $24 \%$. Bila divisualisasikan, tampak jelas perbedaannya pada gambar 1 .

Dilihat dari banyaknya (f) pemilih alternatif skor jawaban, data sebelum perkuliahan dan sesudah perkuliahan dapat dilihat pada tabel 1.

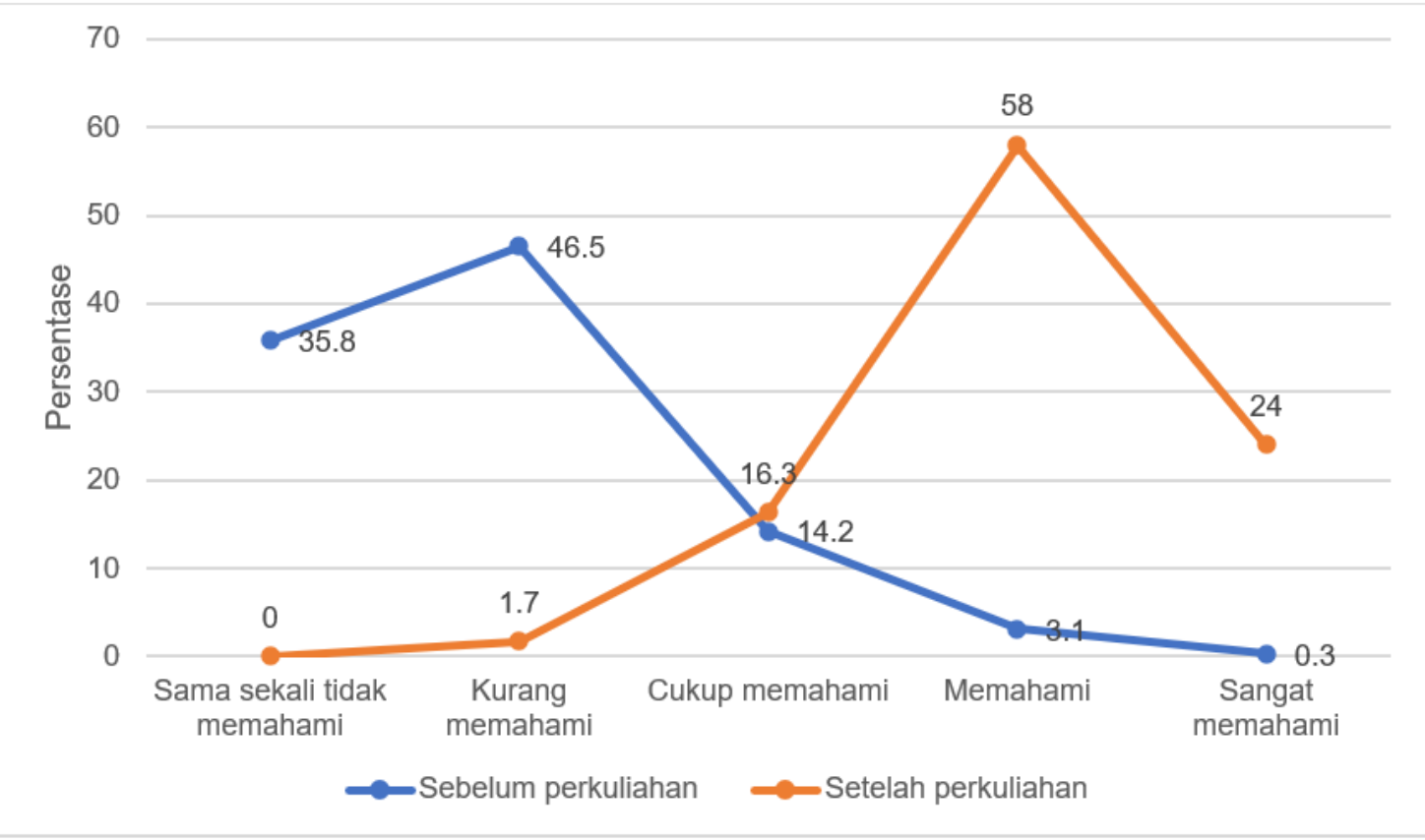

Gambar 1.

Pemahaman tentang Manfaat Memahami Profil Capaian Tugas Perkembangan Siswa SD (\%)

Tabel 1.

Pemahaman tentang Manfaat Memahami Profil Capaian Tugas Perkembangan Siswa SD (f) 


\begin{tabular}{|c|c|c|c|}
\hline \multicolumn{2}{|c|}{ Alternatif Jawaban } & Sebelum (f) & Sesudah (f) \\
\hline & 0 & 103 & 0 \\
\hline & 1 & 134 & 5 \\
\hline cror & 2 & 41 & 47 \\
\hline SKO & 3 & 9 & 167 \\
\hline & 4 & 1 & 69 \\
\hline & Total & 288 & 288 \\
\hline
\end{tabular}

Setelah perkuliahan melibatkan perangkat lunak ATP, mahasiswa memiliki pemahaman tambahan tentang pentingnya memiliki memahaman tentang capaian tugas perkembangan siswa SD. Siswa SD memiliki karakteristik yang unik. Sebagaimana konsep utama perkembangan bahwa setiap fase memiliki kekhasan tersendiri. Pemahaman calon guru terkait perkembangan peserta didik dapat memfasilitasi pendidikan karakter pada anak sesuai dengan karakteristik unik yang dimilikinya (Cahyono \& Iswati, 2018). Alasan lain pentingnya guru atau calon guru memahami perkembangan anak adalah mengantisipasi berbagai kemungkinan yang memfasilitasi atau mengganggu proses optimalisasi perkembangan anak (Latifa, 2017).

Dalam pembentukan akhlak dan kepribadian, guru tidak bisa sembarangan memperlakukan siswa. Tugas guru bukan hanya sekedar transfer knowledge, namun secara komprehensif perlu membina dan mengembangkan bakat anak didik ke arah yang maksimal (Wahid, 2013). Urgensi utama memahami perkembangan peserta didik adalah untuk menyesuaikan perlakukan pembelajaran (lebih jauh, pendidikan) yang diselenggarakan guru (Samiudin, 2017).

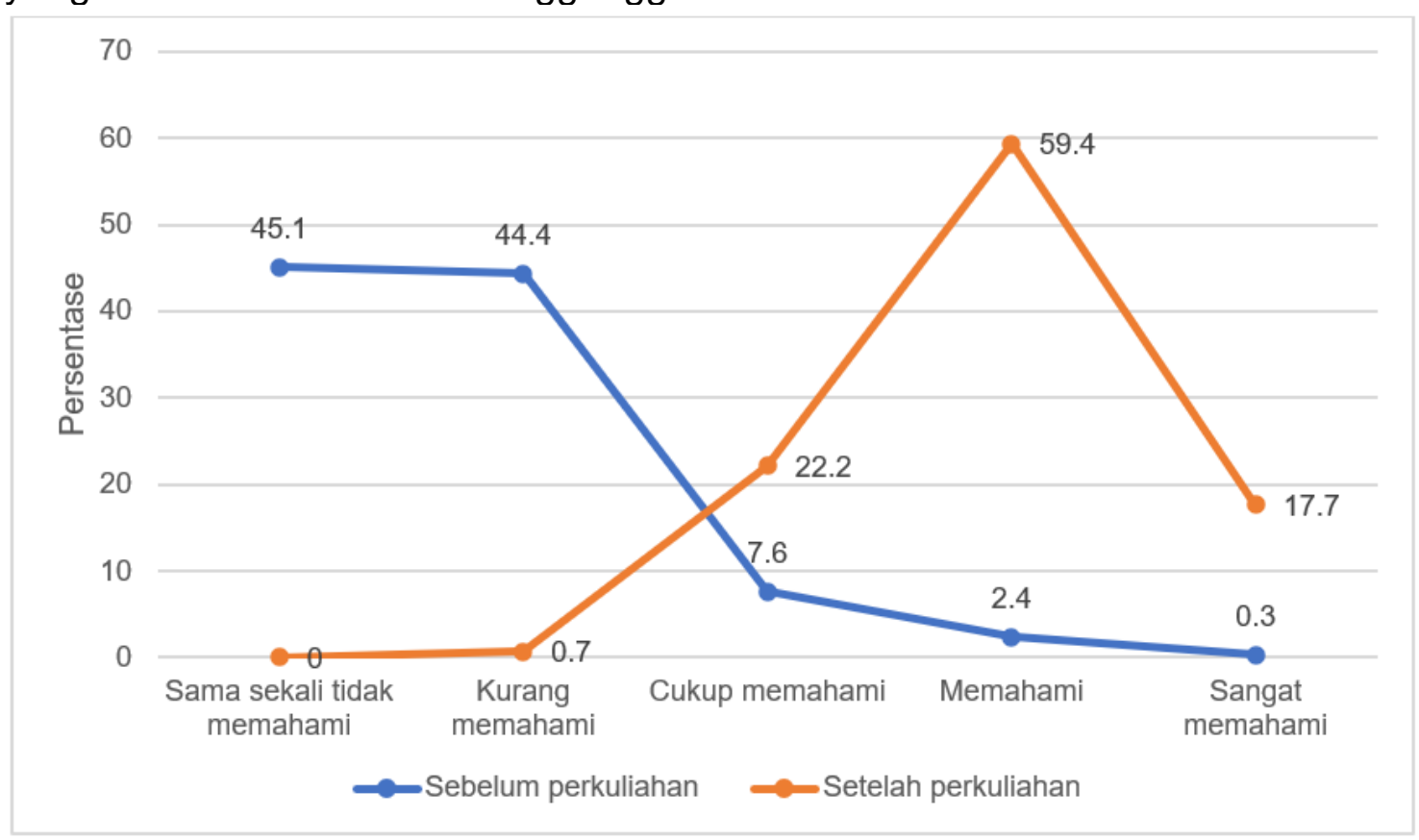

Gambar 2.

Pemahaman tentang Aspek Perkembangan Siswa SD (\%) 
Kedua. Pemahaman tentang aspek perkembangan siswa SD. Dari hasil proses perkuliahan menggunakan ITP dan ATP diketahui peningkatan menyolok antara sebelum perkuliahan dengan sesudah perkuliahan. Mahasiswa pada kategori sama sekali tidak memahami mendominasi dengan persentase $45.1 \%$. Mahasiswa pada kategori kurang memahami sebanyak $44.4 \%$,

Mahasiswa pada kategori cukup memhamai $7.6 \%$, dan mahasiswa pada kategori memahami sebanyak $2.4 \%$, dan pada kategori sangat memahami hanya $0.3 \%$.

Setelah perkuliahan mahasiswa pada kategori sama sekali tidak memahami menurun menjadi $0 \%$ dan mahasiswa pada kategori kurang memahami menjadi $0,7 \%$. Sementara itu, mahasiswa pada kategori cukup memahami meningkat menjadi $22.2 \%$, pada kategori memahami meningkat menjadi $59.4 \%$, dan kategori sangat memahami meningkat menjadi $17,7 \%$. Secara visual hasil perbandingannya dapat dilihat pada gambar 2 .

Tabel 2.

Pemahaman tentang Aspek Perkembangan Siswa SD (f)

\begin{tabular}{cccc}
\hline \multicolumn{1}{c}{ Alternatif Jawaban } & Sebelum (f) & Sesudah (f) \\
& 0 & 130 & 0 \\
\multirow{4}{*}{ Skor } & 1 & 128 & 2 \\
& 2 & 22 & 64 \\
& 3 & 7 & 171 \\
& 4 & 1 & 51 \\
& Total & 288 & 288 \\
\hline
\end{tabular}

Bila dilihat dari frekuensinya, hasil perbandingan sebelum dan sesudah perkuliahan menggunakan perangkat lunak ATP dapat dilihat pada tabel 2.

Perkembangan merupakan perubahan perilaku yang dilandasi aspek psikis seseorang. Perubahan ini terjadi pada setiap orang melalui habituasi dan latihan. Melalui belajar, anak memperoleh kemampuan menggunakan sumber daya diri mendapatkan kesempatan belajar untuk berkembang (Hurlock dalam Assingkily \& Hardiyati, 2019).

Bahkan menurut Prastowo (2014) salah satu problematika pendidikan di Indonesia adalah tidak terfasilitasinya kondisi psikologis siswa dalam proses pembelajaran. Oleh karena itu pembelajaran terpadu dihadirkan atas dasar untuk memfasilitasi tingkat perkembangan siswa secara psikologis. Dengan demikian, lagi-lagi pemahaman tentang profil perkembangan siswa secara komprehensif menjadi dasar bagi penyelenggaraan pembelajaran yang berhasil efektif. Fondasi utama studi ini berangkat dari asumsi bahwa pemahaman yang baik terhadap karakteristik kebutuhan perkembangan peserta didik di SD merupakan kunci bagi keberhasilan proses pembelajaran (Prastowo, 2014).

Ketiga.

Keterampilan mendeskripsikan profil tingkatan capaian tentang tugas aspek-aspek perkembangan siswa SD. Dari hasil proses perkuliahan menggunakan ITP dan ATP diketahui peningkatan menyolok antara sebelum perkuliahan dengan sesudah perkuliahan. Sebelum perkulihan mahasiswa pada 
kategori sama sekali tidak terampil mendominasi dengan presentase $61.5 \%$.

Mahasiswa pada kategori kurang terampil $30.9 \%$, pada kategori cukup terampil $5.6 \%$, kategori terampil sangat rendah dengan presentase $1.7 \%$, dan mahasiswa pada katagori sangat terampil $0.3 \%$. Setelah perkuliahan, tidak ada lagi mahasiswa pada kategori sama sekali tidak terampil $0 \%$ dan mahasiswa pada kategori kurang terampil menurun menjadi $3.5 \%$. Sementara itu, mahasiswa pada kategori cukup terampil meningkat menjadi $30.6 \%$, mahasiswa pada kategori terampil meningkat menjadi $56.3 \%$, dan kategori sangat terampil meningkat menjadi $9.7 \%$. Bila digambarkan dapat dilihat pada gambar 3 .

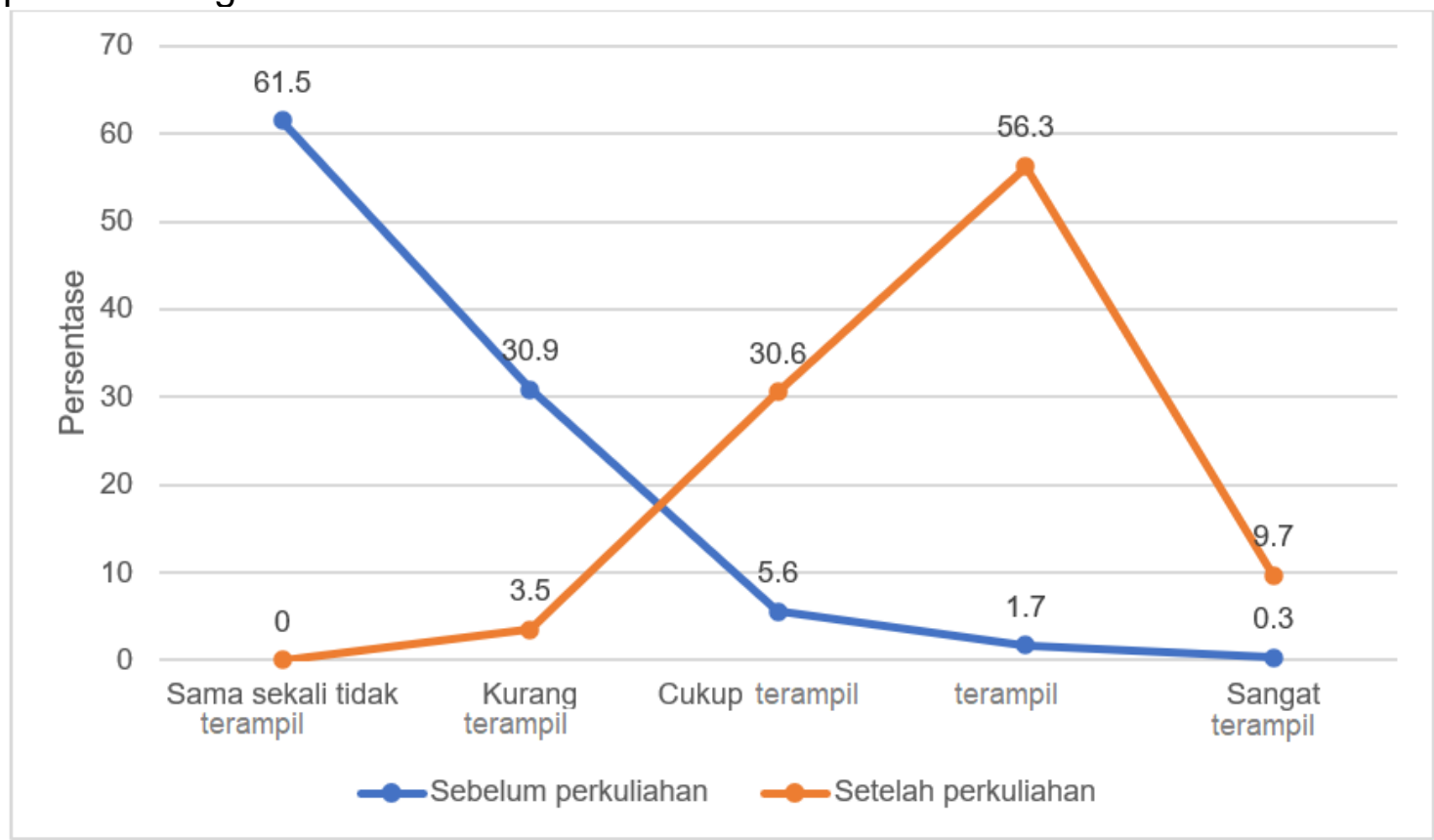

Gambar 3.

Keterampilan Mendeskripsikan Profil Tingkatan Capaian Tugas AspekAspek Perkembangan Siswa SD

Bila dilihat dari frekuensinya, perangkat lunak ATP dapat dilihat hasil perbandingan sebelum dan pada tabel 3 . sesudah perkuliahan menggunakan

Tabel 3.

Keterampilan Mendeskripsikan Profil Tingkatan Capaian Tugas Aspek-

Aspek Perkembangan Siswa SD

\begin{tabular}{cccc}
\hline \multicolumn{1}{c}{ Alternatif Jawaban } & Sebelum (f) & Sesudah (f) \\
\hline \multirow{4}{*}{ Skor } & 0 & 177 & 0 \\
& 1 & 89 & 10 \\
& 2 & 16 & 88 \\
& 3 & 5 & 162 \\
& 4 & 1 & 28 \\
& Total & 288 & 288 \\
\hline
\end{tabular}


Ada 10 aspek perkembangan siswa SD: (1) landasan hidup religius; (2) landasan perilaku etik; kematangan emosional; kematangan intelektual; (5) kesadaran tanggung jawab; (6) peran sosial sebagai pria dan wanita; (7) penerimaan diri dan pengembangannya; (8) kemandirian perilaku ekonomis; (9) wawasan dan persiapan karir; dan (10) kematangan hubungan dengan teman sebaya.

Untuk siswa SD terdiri dari 4 tingkatan pencapaian tugas perkembangan. Tingkat implusif. Memiliki ciri-ciri memiliki identitas diri sebagai bagian yang terpisah dari orang lain. pola perilaku menuntut dan bergantung pada lingkungansebagai sumber ganjaran dan hukuman, serta berorientasi sekarang (tidak berorientasi pada masa lalu atau masa depan). Individu tidak menempatkan diri sebagai faktor penyebab perilaku.

Tingkat perlindungan diri. Memiliki ciri-ciri peduli terhadap kontroldan keuntungan yang dapat diperoleh dari berhubungan dengan orang lain. Mengikuti aturan secara oportunistik dan hedonistik (prinsip

menyenangkan diri).Berpikir tidak logis dan stereotip.Cenderung melihat kehidupan sebagai "zero-sum game". Cenderung menyalahkan dan mencela orang lain dengan lingkungan.

\section{Tingkat}

Memiliki ciri-ciri yang meliputi: peduli terhadap penampilan diri dan penerimaan sosial, cenderung berpikir sterotip dan klise, peduli akan peraturan eksternal, bertindak dengan motif dangkal (untuk memperoleh pujian), menyamakan diri dalam ekspresi emosi, kurang intropeksi, perbedaan kelompok didasarkan atas cirir-ciri eksternal, takut tidak diterima kelompok, tidak sensitif terhadap keindividualan, dan merasa berdosa jika melanggar aturan.

Tingkat sadar diri.
Memiliki ciri-ciri yang meliputi: mampu berfikir alternatif, melihat harapan dan berbagai kemungkinan dalam situasi, peduli untuk mengambil manfaat dari kesempatan yang ada, orientasi pemecahan masalah, memikirkan cara hidup, dan penyesuaian terhadap situasi dan peranan.

\section{SIMPULAN}

Perangkat lunak ATP dalam mengolah data ITP yang dilibatkan pada mata kuliah Perkembangan Peserta Didik di SD memberikan peningkatan pemahaman mahasiswa calon guru SD tentang manfaat mempelajari aspek dan tugas perkembangan;

pemahaman tentang aspek-aspek perkembangan; dan memungkinkan meningkatkan keterampilan dalam mendeskripsikan profil tingkatan capaian tugas aspek-aspek perkembangan siswa SD.

Oleh karena simpulan tersebut, implikasinya adalah ITP dan ATP perlu disosialisasikan kepada para pendidik calon guru (Dosen) untuk digunakan dalam perkuliahan pemahaman peserta didik khususnya mata kuliah Perkembangan Peserta Didik di SD. Dengan demikian, rekomendasinya adalah diadakan pelatihan penggunaan ITP dan perangkat lunak ATP kepada para dosen pengampu mata kuliah sejenis agar dapat membekali mahasiswa calon guru SD memahami perkembangan anak didiknya sehingga kelak dapat memperlakukan siswa dengan tepat dan berkembang secara optimal. 


\section{DAFTAR PUSTAKA}

Akinlua, S. (2020). A Review of Experimental and Ex Post Facto Research Designs. 10 Juni 2020. Online: https://www.researchgate.net/publication/339433841_A Review_of_Experimental_and_E x_Post_Facto_Research_Design s/citation/download

Assingkily, M. S., \& Hardiyati, M. (2019). Analisis Perkembangan Sosial-Emosional Tercapai dan Tidak Tercapai Siswa Usia Dasar. Al-Aulad: Journal of Islamic Primary Education, 2(2), 19-31. https://doi.org/10.15575/alaulad.v2i2.5210

Aulia, E., \& Djunaidi, D. (2017). Rekayasa Sistem Informasi Analisis Perkembangan Siswa dalam Layanan Bimbingan dan Konseling. Edu Lektrika Journal, 6(1), 16-24.

Avcı, N., Kara, C., Ayhan, S., Güngör, N., \& Kayacık, K. (2014). Investigation of Prospective Teachers' Understanding of Childhood. Procedia - Social and Behavioral Sciences, 152, 246252. https://doi.org/10.1016/j.sbspro.20 14.09.188

Cahyono, H., \& Iswati, I. (2018). Memahami Peran Dan Fungsi Perkembangan Peserta Didik Sebagai Upaya Implementasi Nilai Pendidikan Karakter Dalam Kurikulum. Elementary: Jurnal IImiah Pendidikan Dasar, 4(1), 47. https://doi.org/10.32332/elementa ry.v4i1.1031

Coulombe, B. R., \& Yates, T. M. (2018). Prosocial Pathways to Positive Adaptation: The Mediating Role of Teacher-Child Closeness. Journal of Applied
Developmental Psychology, 58(August), 9-17. https://doi.org/10.1016/j.appdev.2 018.08 .003

Daniels, D. H., \& Shumow, L. (2003). Child Development and Classroom Teaching: A Review of The Literature and Implications for Educating Teachers. Journal of Applied Developmental Psychology, 23(5), 495-526. https://doi.org/10.1016/S01933973(02)00139-9

Dina, R. (2020). Analisis Pencapaian Tugas Perkembangan Siswa SD Negeri Serayu Yogyakarta. Jurnal Serunai Bimbingan Dan Konseling, 9(1), 1-6.

Goble, P., Sandilos, L. E., \& Pianta, R. C. (2019). Gains in Teacher-Child Interaction Quality and Children's School Readiness Skills: Does it Matter Where Teachers Start? Journal of School Psychology, 73(February 2018), 101-113. https://doi.org/10.1016/j.jsp.2019. 03.006

Latifa, U. (2017). Aspek Perkembangan pada Anak Sekolah Dasar: Masalah dan Perkembangannya. Academica: Journal of Multidisciplinary Studies, 1(2), 185-196.

Pakarinen, E., \& Kikas, E. (2019). Child-Centered and TeacherDirected Practices in Relation to Calculation and Word Problem Solving Skills. Learning and Individual Differences, 70(January), 76-85.

https://doi.org/10.1016/j.lindif.201 9.01 .008

Prastowo, A. (2014). Pemenuhan Kebutuhan Psikologis Peserta Didik SD/MI melalui 
Pembelajaran Tematik-Terpadu. JPSD: Jurnal Pendidikan Sekolah Dasar, 1(1), 1-13.

Saeed, S. (2012). Evaluate the Opinions About the Competencies of Prospective Teachers in the Field of Psychology. Procedia - Social and Behavioral Sciences, 47, 908-912.

https://doi.org/10.1016/j.sbspro.20 12.06.755

Samiudin. (2017). Pentingnya

Memahami Perkembangan Anak

Untuk Menyesuaikan Cara

Mengajar yang Diberikan.

Pancawahana: Jurnal Studi Islam, 12(1), 1-9.

Silver, R. B., Measelle, J. R., Armstrong, J. M., \& Essex, M. J. (2005). Trajectories of Classroom Externalizing Behavior:

Contributions of Child

Characteristics, Family

Characteristics, and The

Teacher-Child Relationship

During The School Transition.

Journal of School Psychology, 43, 39-60.

https://doi.org/10.1016/j.jsp.2004.

11.003

Uerz, D., Volman, M., \& Kral, M.

(2018). Teacher Educators'

Competences in Fostering

Student Teachers' Proficiency in

Teaching and Learning with

Technology: An Overview of

Relevant Research Literature.

Teaching and Teacher Education, 70, 12-23.

https://doi.org/10.1016/j.tate.2017 .11 .005

Wahid, A. (2013). Guru Sebagai Figur Sentral Dalam Pendidikan.

Sulesana, 8(27), 4.

http://journal.uin-

alauddin.ac.id/index.php/sls/articl e/view/1273
Kementerian Pendidikan Nasional. Direktorat Jenderal Peningkatan Mutu Pendidik dan Tenaga Kependidikan. 2010. Pedoman Pelaksanaan Penilaian Kinerja Guru (PK Guru). Jakarta. 